\title{
EVALUATION OF TWO GENERA OF BENTHIC FORAMINIFERA FOR DOWN-CORE PALEOTEMPERATURE STUDIES IN THE WESTERN SOUTH ATLANTIC
}

\author{
Karen B. Costa ${ }^{l}$; Felipe A. L. Toledo ${ }^{1}$; Maria A.G. Pivel ${ }^{1}$; Cândido A.V. Moura ${ }^{2}$ \& Farid Chemale Jr. ${ }^{3}$ \\ ${ }^{1}$ Instituto Oceanográfico da Universidade de São Paulo \\ Laboratório de Paleoceanografia do Atlântico Sul \\ (Praça do Oceanográfico, 191, 05508-120 São Paulo, SP, Brasil) \\ karen.costa@io.usp.br \\ ${ }^{2}$ Universidade Federal do Pará \\ Laboratório de Geologia Isotópica, Pará-Iso, CG \\ (Caixa Postal 1611, Belém, PA, Brasil) \\ ${ }^{3}$ Universidade Federal do Rio Grande do Sul \\ Laboratório de Geologia Isotópica, IG \\ (Caixa Postal 15001, Porto Alegre, RS, Brasil)
}

\begin{abstract}
A B S TRACT
In this study we have compared the oxygen isotopic composition of two genera of benthic foraminifera (Uvigerina and Cibicidoides) from core-top samples with modern oxygen isotopic composition of seawater $\left(\delta^{18} \mathrm{O}_{\mathrm{w}}\right)$. Based on a new relationship between $\delta^{18} \mathrm{O}_{\mathrm{w}}$ and salinity for the mid-latitude western South Atlantic, we estimated the isotopic composition of equilibrium calcite $\left(\delta^{18} \mathrm{O}_{\text {eq }}\right)$ using two different equations: (1) O'Neil et al. (1969), modified by McCorkle et al. (1997) and (2) Kim \& O'Neil (1997). When using (1), the small difference between $\delta^{18} \mathrm{O}_{\mathrm{eq}}$ and $\delta^{18} \mathrm{O}$ of Uvigerina suggests that this genus precipitates its shell close to equilibrium with ambient seawater. The $\delta^{18} \mathrm{O}$ Cibicidoides data are $0.82 \%$ lower than the predicted (equilibrium) oxygen isotopic composition. Conversely, using (2) the Cibicidoides $\delta^{18} \mathrm{O}$ data show excellent agreement with the oxygen isotopic composition predicted from $\delta^{18} \mathrm{O}$ and water temperature while Uvigerina $\delta^{18} \mathrm{O}$ data are $0.69 \%$ higher than predicted oxygen isotope equilibrium values. Based on the evidences presented here and on the results from previous studies we suggest using the genus Cibicidoides and applying Kim \& O'Neil's (1997) equation for down-core paleotemperature investigations. In the absence of enough Cibicidoides specimens we suggest using Uvigerina $\delta^{18} \mathrm{O}$ data and applying a correction factor of $-0.69 \%$.
\end{abstract}

\section{R ES UMO}

Neste estudo, compara-se a composição de isótopos de oxigênio de dois gêneros de foraminíferos bentônicos (Uvigerina e Cibicidoides) de amostras de topo de testemunho com a composição isotópica moderna da água do $\operatorname{mar}\left(\delta^{18} \mathrm{O}_{\mathrm{w}}\right)$. Baseados em uma nova relação entre $\delta^{18} \mathrm{O}_{\mathrm{w}}$ e salinidade para a latitude média do Atlântico Sul ocidental, estimou-se a composição isotópica da calcita em equilíbrio $\left(\delta^{18} \mathrm{O}_{\mathrm{eq}}\right)$ a partir de duas equações diferentes: (1) O'Neil et al. (1969), modificada por McCorkle et al. (1997) e (2) Kim \& O'Neil (1997). Utilizando (1), a pequena diferença entre $\delta^{18} \mathrm{O}_{\mathrm{eq}} \mathrm{e}$ $\delta^{18} \mathrm{O}$ de Uvigerina sugere que este gênero precipita as suas testas próximo ao equilíbrio com a água. Já os dados de $\delta^{18} \mathrm{O}$ de Cibicidoides são $0,82 \%$ menores que a composição isotópica prevista. Ao contrário, utilizando (2) os dados de $\delta^{18} \mathrm{O}$ de Cibicidoides mostram uma concordância excelente com a composição isotópica esperada, enquanto que os dados de $\delta^{18} \mathrm{O}$ de Uvigerina são $0,69 \%$ maiores que os valores de equilíbrio previstos. A partir das evidências apresentadas neste trabalho e em estudos prévios sugerimos a utilização do gênero Cibicidoides e a aplicação da equação de Kim \& O'Neil (1997) para pesquisas de paleotemperatura. Na ausência de suficientes espécimens de Cibicidoides sugerimos a utilização de $\delta^{18} \mathrm{O}$ de Uvigerina aplicando um fator de correção de $0,69 \%$.

Descriptors: Benthic foraminifera, Oxygen isotopes, Palaeoceanography, Paleothermometry.

Descritores: Foraminíferos bentônicos, Isótopos de oxigênio, Paleoceanografia, Paleotermometria. 


\section{INTRODUCTION}

The isotopic and elemental studies of benthic foraminifera species are fundamental to the knowledge of the circulation and chemistry of the oceans in the past, and are used to reconstruct variations in the models of intermediate and deep water circulation and their intensity in terms of glacial-interglacial oscillations. Glacial-interglacial fluctuations of foraminifera $\delta^{18} \mathrm{O}$ combine signs of changing temperature and changing $\delta^{18} \mathrm{O}$ of seawater $\left(\delta^{18} \mathrm{O}_{\mathrm{w}}\right)$ (Shackleton, 1967). The cyclical variations of benthic foraminifera $\delta^{18} \mathrm{O}$ values through time permit the determination of a stratigraphic time scale, from which it is possible to correlate different sediment cores. Because the $\delta^{18} \mathrm{O}$ of calcite $\left(\delta^{18} \mathrm{O}_{\mathrm{c}}\right)$ increases as calcification temperatures decrease, the $\delta^{18} \mathrm{O}$ in foraminifera can be used as a paleothermometer (Emiliani, 1955). Several paleotemperature equations have been proposed based on the oxygen isotopic composition of calcium carbonate. McCrea (1950) produced the first empirical relationship between temperature and $\delta^{18} \mathrm{O}$ for inorganically precipitated calcite. Epstein et al. (1953) calibrated the equation for mollusks precipitating their shells at known temperatures, showing the potential for paleothermometry of oxygen isotopes of biogenically precipitated calcite. Some improvements in the equation for mollusks were made by Craig \& Gordon (1965) and in the equation based on calcite precipitated inorganically at temperatures of $0^{\circ}-500^{\circ} \mathrm{C}$ by O'Neil et al. (1969). Based on the analysis of the oxygen isotopic composition of the benthic foraminifera Uvigerina, Shackleton (1974) suggested a linearization of the low temperature $\left(<16.9^{\circ} \mathrm{C}\right)$ portion of the relationship originally proposed by $\mathrm{O}^{\prime} \mathrm{Neil}$ et al. (1969). The first paleotemperature equation developed for planktonic foraminifera was proposed by Erez \& Luz (1983) based on laboratory culture experiments. Later, Kim \& O'Neil (1997) re-examined the temperature- $\delta^{18} \mathrm{O}$ relationship for inorganically precipitated calcite at low temperatures $\left(10^{\circ}-40^{\circ} \mathrm{C}\right)$ and proposed a new expression. Bemis et al. (1998) reassessed $\delta^{18} \mathrm{O}$ data for planktonic foraminifera and revised the available paleotemperature equations.

According to the equations proposed by O'Neil et al. (1969) and Kim \& O'Neil (1997), for every $1{ }^{\circ} \mathrm{C}$ decrease in temperature there is an increase in the fractionation of inorganically precipitated calcite and water of around $0.2 \%$. Although this relationship is generally observed in the isotopic composition of benthic foraminifera (Shackleton, 1974; Herguera, et al., 1992), the absolute values of $\delta^{18} \mathrm{O}_{\mathrm{c}}$ of some species may present a deviation from equilibrium (Lynch-Stieglitz, et al., 1999). The exact $\delta^{18} \mathrm{O}$ value of equilibrium calcite precipitation $\left(\delta^{18} \mathrm{O}_{\text {eq }}\right)$ depends on the choice of the equilibrium equation.

An assumption implicit in all paleoceanographic studies is that the oxygen isotopic composition $\left(\delta^{18} \mathrm{O}\right)$ of the foraminifera accurately reflects the temperature and oxygen isotopic composition of the seawater in which it grew. However, the isotopic record is not the same for every living organism because some of them (including some benthic foraminifera species) do not precipitate their shells in isotopic equilibrium with the surrounding seawater (Duplessy et al., 1980). Some laboratory experiments using living foraminifera (Spero, 1992; Spero et al., 1997) have demonstrated that the photosynthetic activity of algal symbionts and the carbonate ion concentration of water can affect the oxygen isotopic composition of the shells. Other experiments (Bijma et al., 1999) suggest that $\mathrm{pH}$ is the controlling factor affecting the oxygen isotopic composition. The effect seems to be species dependent and, thus, the calibration of the response in Recent foraminifera is a necessary precondition for the quantitative interpretation of the down-core isotopic record.

The most straightforward approach to the evaluation of the paleoclimatic and paleoceanographic utility of isotopic measurements in benthic foraminifera is the analysis of core-top samples. Coretop calibration studies are based on comparisons of foraminiferal data and modern physical oceanographic parameters. This sort of study has made progress toward calibrating core-top benthic foraminifera isotopic measurements under modern oceanographic conditions in the Pacific (Keigwin, 1998), Indian (McCorkle et al., 1998) and North Atlantic Oceans (Lynch-Stieglitz et al., 1999). However, little attention has been paid to the western South Atlantic despite its fundamental role in global thermohaline deep water circulation as the pathway for the major deep water masses, the North Atlantic Deep Water (NADW), the Circumpolar Deep Water (CPDW), and the Antarctic Bottom Water (AABW) (Berger \& Wefer, 1996).

In this study we focus on the calibration of two different oxygen isotopic equilibrium equations using western South Atlantic core-tops and water column data to determine oxygen isotope fractionation in the benthic foraminifera genera Cibicidoides and Uvigerina as a function of temperature. The relationship between isotopic variation in this data set and modern physical oceanographic parameters provides a realistic framework within which downcore isotopic records may be interpreted.

\section{Methods}

We compare the oxygen isotopic composition of two genera of benthic foraminifera 
from core-top samples with modern oxygen isotopic composition of seawater from similar depths at neighboring Geochemical Ocean Sections Study (GEOSECS) stations (Bainbridge, 1981) (Fig. $1)$.

The oxygen isotope measurements were made on Cibicidoides and Uvigerina benthic foraminifera. The species generally used in paleoceanographic reconstruction is Cibicidoides wuellerstorfi. However, other species (e.g. C. kullenbergi) closely resemble $C$. wuellerstorfi for isotope analysis (McCorkle et al., 1997). Whenever the abundance of $C$. wuellerstorfi was too low (less than two individuals larger than $250 \mu \mathrm{m}$ per gram) we used $C$. kullenbergi for isotope analysis.

The foraminifera were picked from the top centimeters of six piston cores and four box-cores from intermediate depths (965-1995 m) on the Brazilian Continental Margin (Table 1, Fig. 1). Additional cores from the same depth range and deeper (Curry \& Lohmann, 1982; Oppo \& Horowitz, 2000) were included in our study in order to provide a more complete and confident dataset to be used in paleoceanographic reconstructions. The additional cores are close to the core-top locations of this study (Table 1, Fig. 1).

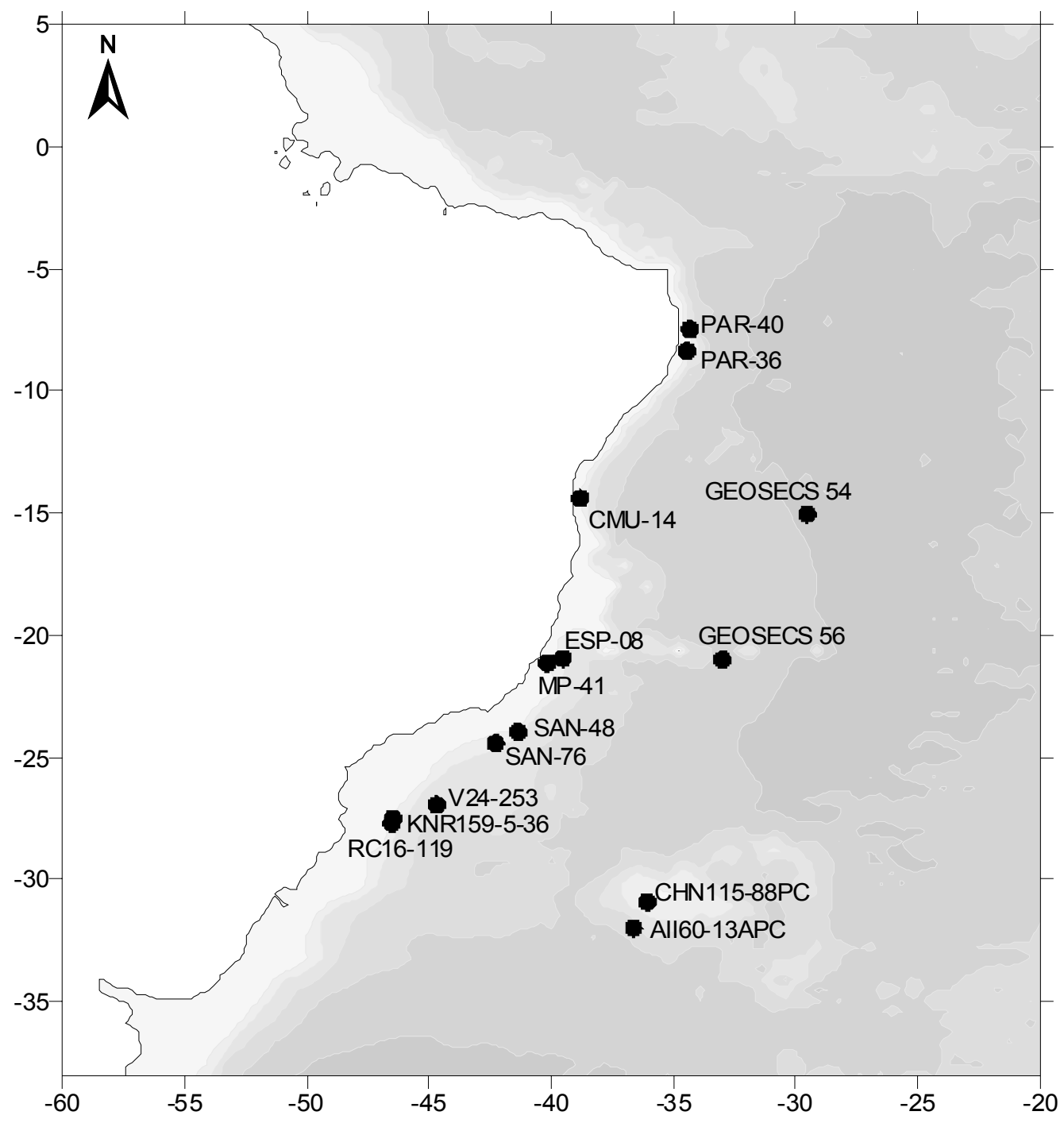

Fig. 1. Location of GEOSECS and core-top sampling stations. Box-cores MP-02, MP-14 and MP-33 are in the same area as box-core MP-41. 
Table 1. Core locations and sample type $(\mathrm{BC}=$ box-core, $\mathrm{PC}=$ piston core $)$.

\begin{tabular}{|c|c|c|c|c|c|}
\hline Core & Latitude & Longitude & Depth & Type & Source \\
\hline MP-02 & $21^{\circ} 08 ’ 19 ” S$ & $40^{\circ} 10^{\prime} 15^{\prime \prime} \mathrm{W}$ & 903 & $\mathrm{BC}$ & This study \\
\hline MP-14 & $21^{\circ} 08^{\prime} 16^{\prime \prime} \mathrm{S}$ & $40^{\circ} 10^{\prime} 14^{\prime \prime} \mathrm{W}$ & 903 & $\mathrm{BC}$ & This study \\
\hline MP-33 & $21^{\circ} 08 ' 25 " \mathrm{~S}$ & $40^{\circ} 10^{\prime} 25^{\prime \prime} \mathrm{W}$ & 884 & $\mathrm{BC}$ & This study \\
\hline MP-41 & $21^{\circ} 08^{\prime} 29^{\prime \prime} \mathrm{S}$ & $40^{\circ} 10^{\prime} 01{ }^{\prime \prime} \mathrm{W}$ & 928 & $\mathrm{BC}$ & This study \\
\hline CMU-14 & $14^{\circ} 24^{\prime} 00^{\prime \prime} \mathrm{S}$ & $38^{\circ} 49^{\prime} 12^{\prime \prime} \mathrm{W}$ & 965 & $\mathrm{PC}$ & This study \\
\hline PAR-40 & $7^{\circ} 28^{\prime} 48^{\prime \prime} \mathrm{S}$ & $34^{\circ} 19^{\prime} 48^{\prime \prime} \mathrm{W}$ & 1261 & $\mathrm{PC}$ & This study \\
\hline PAR-36 & $8^{\circ} 22^{\prime} 12^{\prime \prime} \mathrm{S}$ & $34^{\circ} 27^{\prime} 00^{\prime \prime} \mathrm{W}$ & 1315 & $\mathrm{PC}$ & This study \\
\hline SAN-48 & $23^{\circ} 58^{\prime} 12^{\prime \prime} \mathrm{S}$ & $41^{\circ} 21^{\prime} 00^{\prime \prime} \mathrm{W}$ & 1568 & $\mathrm{PC}$ & This study \\
\hline SAN-76 & $24^{\circ} 25^{\prime} 48^{\prime \prime} \mathrm{S}$ & $42^{\circ} 16^{\prime} 48^{\prime \prime} \mathrm{W}$ & 1682 & $\mathrm{PC}$ & This study \\
\hline ESP-08 & $20^{\circ} 57^{\prime} 00^{\prime \prime} \mathrm{S}$ & $39^{\circ} 31^{\prime} 48^{\prime \prime} \mathrm{W}$ & 1995 & $\mathrm{PC}$ & This study \\
\hline KNR159-5-36 & $27^{\circ} 30^{\prime} 36^{\prime \prime} \mathrm{S}$ & $46^{\circ} 28^{\prime} 12^{\prime \prime} \mathrm{W}$ & 1268 & $\mathrm{PC}$ & Oppo \& Horowitz (2000) \\
\hline $\mathrm{RC} 16-119$ & $27^{\circ} 42^{\prime} 00^{\prime \prime} \mathrm{S}$ & $46^{\circ} 31^{\prime} 12^{\prime \prime} \mathrm{W}$ & 1567 & $\mathrm{PC}$ & Oppo \& Horowitz (2000) \\
\hline$V 24-253$ & $26^{\circ} 5700^{\prime \prime} \mathrm{S}$ & $44^{\circ} 40^{\prime} 48^{\prime \prime} \mathrm{W}$ & 2069 & $\mathrm{PC}$ & Oppo \& Horowitz (2000) \\
\hline AII60-13APC & $31^{\circ} 59^{\prime} 1^{\prime \prime} \mathrm{S}$ & $36^{\circ} 38^{\prime} 9 ’ \mathrm{~W}$ & 2739 & $\mathrm{PC}$ & Curry \& Lohmann (1982) \\
\hline CHN115-88PC & $30^{\circ} 55^{\prime} 0 ” \mathrm{~S}$ & $36^{\circ} 04^{\prime} 8^{\prime \prime} \mathrm{W}$ & 2941 & $\mathrm{PC}$ & Curry \& Lohmann (1982) \\
\hline
\end{tabular}

The piston cores were sampled at intervals of 5 to $10 \mathrm{~cm}$ from 0 to $25 \mathrm{~cm}$. Accelerator Mass Spectrometer (AMS) radiocarbon datings performed on three samples of planktonic foraminifera (Table 2) confirmed our Marine Isotopic Stage 1 age assignments. Although belonging to Marine Isotope Stage 1, these samples may not represent full interglacial Holocene conditions. In order to identify Holocene samples, the averages of the samples with the lowest $\delta^{18} \mathrm{O}$ values were used to estimate the isotopic composition of Holocene foraminifera. The piston cores oxygen isotope analyses were made on a Finnigan MAT 252 with an automated Kiel device at the Woods Hole Oceanographic Institution laboratory facilities. The standard deviation of the isotope values of the National Bureau of Standards (NBS) carbonate standard NBS-19 was $\pm 0.08 \%$. NBS-19 isotope values were used to calibrate for Pee Dee Belemnite $\left(\delta^{18} \mathrm{O}=-2.2\right.$ Vienna Pee Dee Belemnite (VPDB)).

All the box cores sampled had clear overlying water and visual evidence of minimal sediment disturbance. We collected the top centimeter sediments. Core-top box core samples were disaggregated in distilled water at room temperature, dry-sieved and for each sample 3 or 4 specimens were handpicked in the size fraction greater than the 250 $\mu \mathrm{m}$ sieve to avoid ontogenetic artifacts. Oxygen isotope analyses of box corer samples were performed at the Pará-Iso Laboratory (CG-UFPA) using a Finnigan MAT 252 mass spectrometer. $\mathrm{CO}_{2}$ extraction of single foraminifera shells was done using an on-line KIEL-III system coupled to the instrument. Isotope ratios are reported relative to the Pee Dee Belemnite (PDB) standard, based on the analysis of NBS-19 carbonate standard, reacted with each set of samples. Results are reported in the standard $\delta(\%)$ notation relative to the Chicago PDB standard. The precision of these foraminiferal isotopic analyses is better than $0.08 \%$, based on replicated analysis of the carbonate standard.

Prior to estimating the $\delta^{18} \mathrm{O}_{\mathrm{eq}}$ for the South Atlantic, the regional $\delta^{18} \mathrm{O}_{w^{-}}$salinity relationship had to be established. The linear relationship between $\delta^{18} \mathrm{O}_{\mathrm{w}}$ and salinity was estimated based on the GEOSECS data from station 56, considering the same depth range as that of the cores used in this study (884-2941 m). 
Table 2. Accelerator Mass Spectrometer (AMS) Dates and Calendar Ages.

\begin{tabular}{cccc}
\hline \hline Cores & $\begin{array}{c}\text { Sample } \\
\text { depth }(\mathbf{c m})\end{array}$ & $\begin{array}{c}\text { AMS Date } \\
(\mathbf{k y r})\end{array}$ & $\begin{array}{c}\text { Calendar Age } \\
\mathbf{( k y r )}\end{array}$ \\
\hline SAN-76 & 13 & 3.010 & 2.756 \\
ESP-08 & 07 & 3.370 & 3.219 \\
CMU-14 & 12 & 4.010 & 3.987 \\
\hline
\end{tabular}

\section{Results}

The $\delta^{18} \mathrm{O}$ of seawater primarily reflects patterns of evaporation and fresh water influx to the surface of the oceans. Because salinity also reflects these same processes, salinity and $\delta^{18} \mathrm{O}_{\mathrm{w}}$ are often well correlated in the ocean (Craig \& Gordon, 1965). Although the exact correlation varies in different areas of the ocean surface (Paul et al., 1999), the vast majority of the surface and subsurface waters warmer than $5^{\circ} \mathrm{C}$ follow the surface water trend. The equation resulting from the linear regression of observed $\delta^{18} \mathrm{O}_{\mathrm{w}}$ and observed salinity in the South Atlantic (Fig. 2) may be expressed relative to the Standard Mean Ocean Water (SMOW) as follows:

$\delta^{18} \mathrm{O}_{\mathrm{w} \text { (smow) }}=(0.61 \mathrm{x}$ salinity $)-20.942$

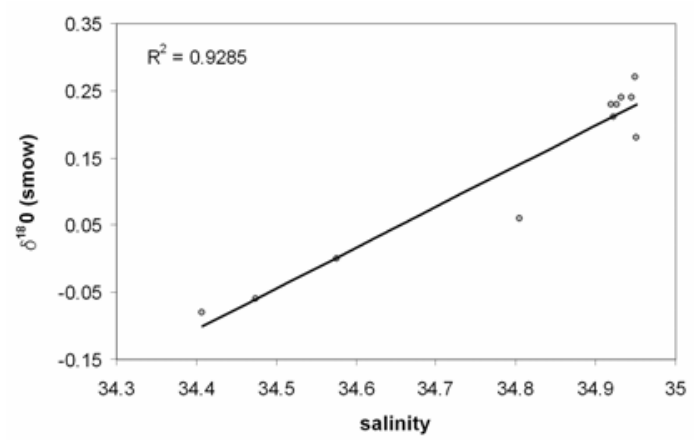

Fig. 2. Plot of $\delta^{18} \mathrm{O}_{\mathrm{w}}(\%)$ versus salinity from GEOSECS station 56 for the depth range of the cores used in this study (884-2941m).

This equation agrees with that calculated by Paul et al. (1999) based on GEOSECS data for midlatitudes. Applying the above relationship, the $\delta^{18} \mathrm{O}_{\mathrm{w}}$ values for GEOSECS stations 54 were estimated.
Based on the $\delta^{18} \mathrm{O}_{\mathrm{w}}$ values calculated from equation (1) and temperature data from the GEOSECS stations, the predicted isotopic values for calcite precipitated in equilibrium with modern bottom water chemistry were calculated using the equations of O’Neil et al. (1969) (eq. 2) and Kim \& O'Neil (1997) (eq. 3) for the oxygen isotope fractionation as between calcite and water:

$1000 \ln \alpha_{\text {(calcite-water) }}=2.78\left(10^{6} \mathrm{~T}^{-2}\right)-3.39$

and

$1000 \ln \alpha_{\text {(calcite-water) }}=18.03\left(10^{3} \mathrm{~T}^{-1}\right)-32.42$

Both equations may be rearranged to give expressions for the calcite precipitated in equilibrium $\left(\delta^{18} \mathrm{O}_{\mathrm{eq}}\right)$ with local bottom water. McCorkle et al. (1997) rearranged the original equation of O'Neil et al. (1969) incorporating a revised estimate of the calcite-water fractionation factor (Friedman \& O'Neil, 1977) as follows:

$\delta^{18} \mathrm{O}_{\mathrm{eq} \text { (smow) }}=\left\{\mathrm{e}^{\left[\left(2.78 \times 1000 / \mathrm{T}^{2}\right)-(2.89 / 1000)\right]} \times\left(\delta^{18} \mathrm{O}_{\mathrm{w}}+\right.\right.$ 1000)\} -1000

The equation derived from (3) to yield the calcite precipitated in equilibrium $\left(\delta^{18} \mathrm{O}_{\text {eq }}\right)$ may be written as:

$\delta^{18} \mathrm{O}_{\text {eq (smow) }}=\left\{\mathrm{e}^{[(18.03 / \mathrm{T})-(32.42 / 1000)]} \times\left(\delta^{18} \mathrm{O}_{\mathrm{w}}+1000\right)\right\}-$ 1000

In equations (4) and (5) temperature values are in degrees Kelvin $\left({ }^{\circ} \mathrm{K}\right)\left[\mathrm{T}\left({ }^{\circ} \mathrm{K}\right)=273.15+\mathrm{T}\left({ }^{\circ} \mathrm{C}\right)\right]$ and $\delta^{18} \mathrm{O}_{\mathrm{eq}}$ is relative to the SMOW standard. Values

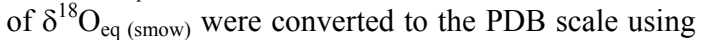
Friedman \& O'Neil's (1977) equation:

$\delta^{18} \mathrm{O}_{\mathrm{eq}(\mathrm{PDB})}=\left(0.97006 \times \delta^{18} \mathrm{O}_{\mathrm{eq}(\text { smow) }}\right)-29.94$

Table 3 reports the foraminifera oxygen isotopic composition $\left(\delta^{18} \mathrm{O}_{\text {foram }}\right)$, the corresponding predicted isotopic values for calcite precipitated in equilibrium with ambient conditions $\left(\delta^{18} \mathrm{O}_{\mathrm{eq}}\right)$ using, respectively, the O'Neil et al.'s (1969) equation, modified by those of McCorkle et al. (1997) and Kim \& O'Neil (1997) equations and the offset values. Benthic foraminiferal $\delta^{18} \mathrm{O}$ values increase regularly with increasing water depth (mirroring the decrease in water temperature). A different behavior is observed as between the Cibicidoides and Uvigerina isotopic record (Fig. 3). 
Table 3. Measured $\delta^{18} \mathrm{O}_{\text {foram }}$, predicted oxygen isotope values for foraminifera shells if precipitated in isotopic equilibrium with seawater $\left(\delta^{18} \mathrm{O}_{\mathrm{eq}}\right)$, and offset from equilibrium values for all samples and for both equations tested. The table also includes the temperature and salinity values for each sample and the corresponding calculated $\delta^{18} \mathrm{O}_{\mathrm{w}}$. Except for $\delta^{18} \mathrm{O}_{\mathrm{w}}$ which is relative to the SMOW standard, all values are relative to the PDB standard.

\begin{tabular}{|c|c|c|c|c|c|c|c|c|c|}
\hline \multirow[b]{2}{*}{ Core } & \multirow[b]{2}{*}{ Genus } & \multirow{2}{*}{$\begin{array}{c}\text { Temp } \\
(\mathbf{K})\end{array}$} & \multirow[b]{2}{*}{ Salinity } & \multirow{2}{*}{$\begin{array}{c}\delta^{18} \mathbf{O}_{\mathrm{w} \text { (SMOW) }} \\
(\% \mathrm{o})\end{array}$} & \multirow{2}{*}{$\begin{array}{c}\delta^{18} \mathrm{O}_{\text {foram (PDB) }} \\
(\%)\end{array}$} & \multirow{2}{*}{$\begin{array}{c}\text { O'Neil et al. } \\
\delta^{18} \mathbf{O}_{\text {eq (PDB) }} \\
(\%)\end{array}$} & \multirow{2}{*}{$\begin{array}{l}(1969) \\
\delta^{18} \mathrm{O} \\
\text { offset }\end{array}$} & \multicolumn{2}{|c|}{ Kim \& O'Neil (1997) } \\
\hline & & & & & & & & $\begin{array}{c}\delta^{18} \mathrm{O}_{\text {eq (PDB) }} \\
(\%)\end{array}$ & $\begin{array}{c}\delta^{18} \mathrm{O} \\
\text { offset }\end{array}$ \\
\hline MP-02 & Uvigerina & 276.83 & 34.41 & -0.10 & 2.90 & 2.99 & 0.09 & 2.21 & -0.69 \\
\hline MP-14 & Uvigerina & 276.83 & 34.41 & -0.10 & 2.94 & 2.99 & 0.05 & 2.21 & -0.73 \\
\hline MP-33 & Uvigerina & 276.83 & 34.41 & -0.10 & 2.88 & 2.99 & 0.11 & 2.21 & -0.67 \\
\hline MP-02 & Cibicidoides & 276.83 & 34.41 & -0.10 & 2.30 & 2.99 & 0.69 & 2.21 & -0.09 \\
\hline MP-14 & Cibicidoides & 276.83 & 34.41 & -0.10 & 2.21 & 2.99 & 0.78 & 2.21 & 0.00 \\
\hline MP-33 & Cibicidoides & 276.83 & 34.41 & -0.10 & 2.19 & 2.99 & 0.80 & 2.21 & 0.02 \\
\hline MP-41 & Cibicidoides & 276.83 & 34.41 & -0.10 & 2.48 & 2.99 & 0.51 & 2.21 & -0.27 \\
\hline CMU-14 & Cibicidoides & 276.83 & 34.53 & -0.03 & 2.36 & 3.07 & 0.71 & 2.29 & -0.07 \\
\hline PAR-40 & Cibicidoides & 277.28 & 34.74 & 0.10 & 2.35 & 3.07 & 0.72 & 2.31 & -0.04 \\
\hline PAR-36 & Cibicidoides & 277.45 & 34.79 & 0.13 & 2.26 & 3.06 & 0.80 & 2.30 & 0.04 \\
\hline SAN-48 & Cibicidoides & 276.61 & 34.89 & 0.19 & 2.55 & 3.34 & 0.79 & 2.56 & 0.01 \\
\hline SAN-76 & Cibicidoides & 276.61 & 34.89 & 0.19 & 2.54 & 3.34 & 0.80 & 2.56 & 0.02 \\
\hline ESP-08 & Cibicidoides & 276.58 & 34.95 & 0.23 & 2.56 & 3.39 & 0.83 & 2.60 & 0.04 \\
\hline KNR159-5-36 & Cibicidoides & 276.30 & 34.50 & -0.05 & 2.40 & 3.19 & 0.79 & 2.40 & 0.00 \\
\hline RC16-119 & Cibicidoides & 276.26 & 34.71 & 0.08 & 2.29 & 3.33 & 1.04 & 2.54 & 0.25 \\
\hline V24-253 & Cibicidoides & 276.39 & 34.93 & 0.21 & 2.39 & 3.42 & 1.03 & 2.63 & 0.24 \\
\hline RC16-84 & Cibicidoides & 276.25 & 34.94 & 0.22 & 2.50 & 3.47 & 0.97 & 2.67 & 0.17 \\
\hline AII60-13APC & Cibicidoides & 276.00 & 34.91 & 0.21 & 2.63 & 3.52 & 0.89 & 2.72 & 0.09 \\
\hline CHN115-88PC & Cibicidoides & 275.84 & 34.91 & 0.20 & 2.62 & 3.56 & 0.94 & 2.75 & 0.13 \\
\hline
\end{tabular}

Equation Derived from O'Neil et al. (1969)

(McCorkle et al., 1997)

The Cibicidoides $\delta^{18} \mathrm{O}$ values increase, from minimal values $(2.19 \%$ ) to maximal values $(2.63 \%)$, while the $\delta^{18} \mathrm{O}$ predicted for calcite precipitated in equilibrium with ambient water values increases from $2.99 \%$ to $3.56 \%$. In this way, the Cibicidoides $\delta^{18} \mathrm{O}$ data do not agree well with the $\delta^{18} \mathrm{O}$ profile calculated from equations (4) and (6). The average offset value is $0.82 \%$. In other words, the $\delta^{18} \mathrm{O}$ Cibicidoides data are $0.82 \%$ lower than the $\delta^{18} \mathrm{O}_{\mathrm{eq}}$ data. A similar pattern of large shifts between $\delta^{18} \mathrm{O}$ predicted for calcite precipitated in equilibrium with ambient water and $\delta^{18} \mathrm{O}$ Cibicidoides using equations like O'Neil et al's (1969) were recorded by Shackleton \& Opdyke (1973) (0.64 \%o), Shackleton (1974) (0.82\%o), Erez \& Luz
(1983) (0.48 \%o) and Herguera et al. (1992) (0.84\%o). These studies noted that Cibicidoides do not precipitate their shells in isotopic equilibrium with ambient water and suggested a correction factor for $\delta^{18} \mathrm{O}$ Cibicidoides.

In contrast to the $\delta^{18} \mathrm{O}$ Cibicidoides data, the $\delta^{18} \mathrm{O}$ Uvigerina shows a better agreement with the $\delta^{18} \mathrm{O}$ predicted from the GEOSECS data profile (Fig. 3 , Table 3$). \delta^{18} \mathrm{O}$ Uvigerina values range from $2.88 \%$ to $2.94 \%$ and $\delta^{18} \mathrm{O}$ predicted for calcite precipitated in equilibrium with ambient water using equations (4) and (6) is $2.99 \%$. The average offset value based on the Uvigerina dataset is $0.08 \%$. In other words, $\delta^{18} \mathrm{O}$ Uvigerina data are $0.08 \%$ lower than the $\delta^{18} \mathrm{O}$ predicted for the GEOSECS data stations 54 and 56 . Assuming that the equation applied is correct, the small difference between $\delta^{18} \mathrm{O}_{\mathrm{eq}}$ and $\delta^{18} \mathrm{O}$ Uvigerina 


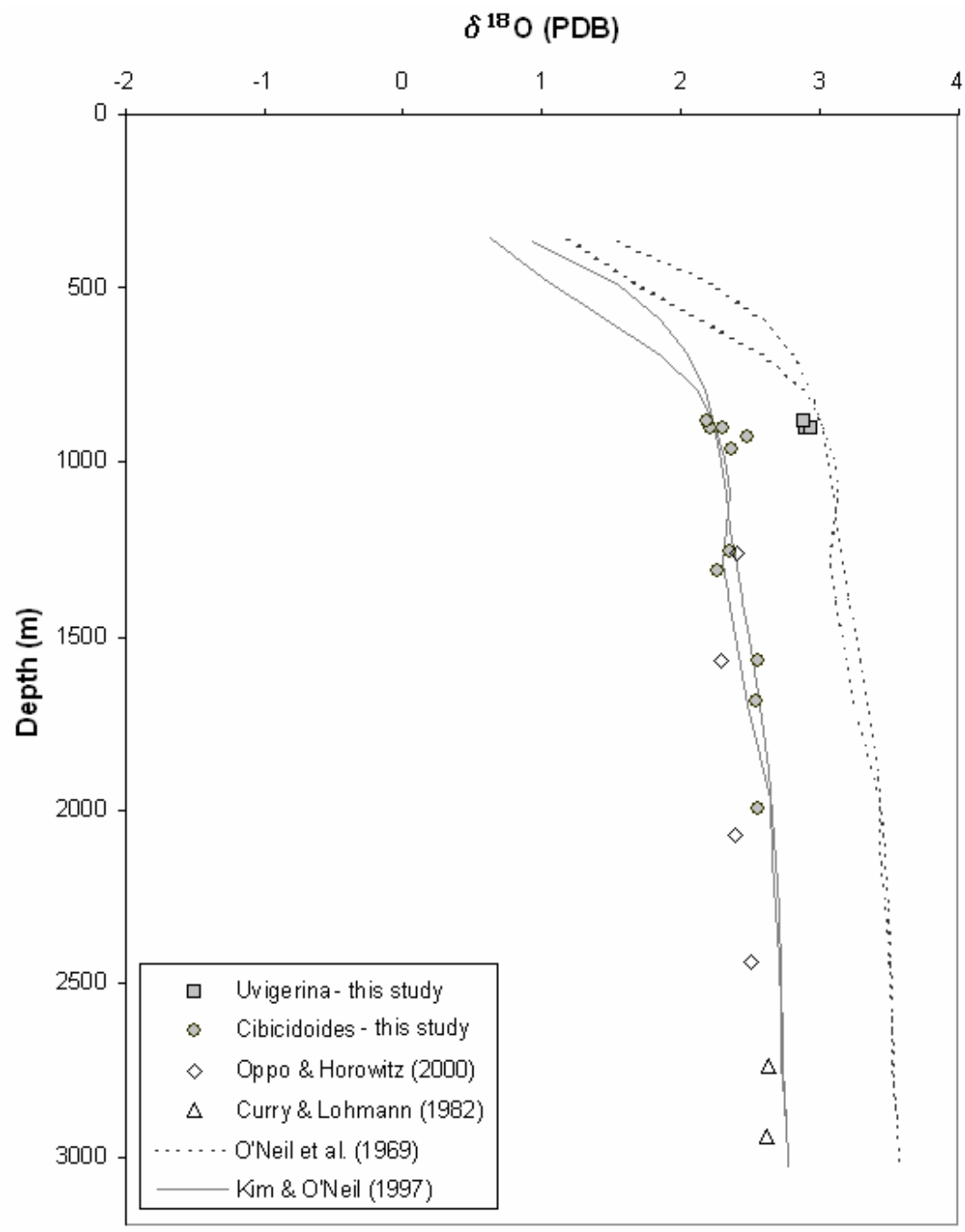

Fig. 3. Comparison of $\delta^{18} \mathrm{O}(\%)$ values from core-top benthic foraminifera Cibicidoides and Uvigerina with $\delta^{18} \mathrm{O}_{\mathrm{eq}}$ values calculated using the equation of O'Neil et al. (1969) modified by McCorkle et al. (1997) and Kim \& O'Neil (1997). Data from Curry and Lohmann (1982) and from Oppo and Horowitz (2000) are of Cibicidoides.

suggests that this latter genus precipitates its shells close to equilibrium with ambient seawater. Several authors (Shackleton \& Opdyke, 1973; Duplessy et al., 1984; Zahn \& Mix, 1991; Herguera et al., 1992; McCorkle et al., 1997) observed a similar response for this genus.

Equation Derived from Kim \& O'Neil (1997)

The Cibicidoides $\delta^{18} \mathrm{O}$ data are in good agreement with the predicted profile calculated from equations (5) and (6). Values range from $2.19 \%$ to $2.63 \%$, while the $\delta^{18} \mathrm{O}$ predicted for calcite precipitated in equilibrium with ambient water values range from $2.21 \%$ to $2.75 \%$ (Fig. 3). The offset calculated for the Cibicidoides dataset has an average value of $0.03 \%$. In other words, the $\delta^{18} \mathrm{O}$ Cibicidoides data are $0.03 \%$ lower than the $\delta^{18} \mathrm{O}$ predicted for GEOSECS data stations 54 and 56.

Conversely, the $\delta^{18} \mathrm{O}$ Uvigerina do not show an agreement with the $\delta^{18} \mathrm{O}$ values predicted for the GEOSECS data profile (Fig. 3, Table 3). The $\delta^{18} \mathrm{O}$ Uvigerina values range from $2.88 \%$ to $2.94 \%$ and the $\delta^{18} \mathrm{O}$ predicted for calcite precipitated in equilibrium with ambient water using equations (5) and (6) is $2.21 \%$. The offset between the predicted 
and observed $\delta^{18} \mathrm{O}$ values for the Uvigerina dataset has an average value of $-0.69 \%$. In other words, $\delta^{18} \mathrm{O}$ Uvigerina data are $0.69 \%$ higher than the $\delta^{18} \mathrm{O}$ predicted for GEOSECS data stations 54 and 56.

\section{Discussion}

The $\delta^{18} \mathrm{O}$ data set as a whole is internally consistent. The small scattering within data is probably easily accounted for by foraminiferal calcification, imperfection of our $\delta^{18} \mathrm{O}_{\mathrm{w}}-$ salinity relationship, post-depositional physical or chemical alterations, and the fact that although the piston core samples were chosen to represent full interglacial conditions they may not be synchronous. Some authors (e.g. Dunbar \& Wefer, 1984; Schmiedl et al., 2004) observed ontogenetic influences on the stable isotopic composition of deep-sea benthic foraminifera. However, it seems unlikely that these influences should have had any effect on our study because excusively adult specimens were picked for analyses. The enrichment of Uvigerina shells relative to Cibicidoides would be consistent with the habitat differences of the genus. Uvigerina is infaunal and experiences lower $\mathrm{pH}$ and decreased $\mathrm{CO}_{2}^{-3}$ concentration in pore waters, whereas Cibicidoides inhabits the sediment surface where bottom water $\mathrm{pH}$ and $\mathrm{CO}_{2}{ }^{-3}$ concentration are higher (McCorkle et al., 1990). In such a scenario the isotopic offset between the foraminifera genus should partially reflect the $\mathrm{CO}_{2}{ }^{-}$ ${ }^{3}$ concentration gradient in the sediments. On the other hand, Mulitza et al. (2003) suggest that the $\mathrm{pH}$ in the vicinity of the shell might be important for the recorded $\delta^{18} \mathrm{O}_{\text {foram }}$ and not the overall $\mathrm{pH}$ gradient in the porewater that determines the difference between the species. This is because local $\mathrm{pH}$ gradients in the upper centimeters of the sediment seem to be too low in most places to explain the differences observed.

It was not previously believed that benthic foraminiferal genus Cibicidoides precipitated its shell in equilibrium with $\delta^{18} \mathrm{O}_{\mathrm{w}}$. The $\delta^{18} \mathrm{O}$ of Cibicidoides appeared to have a consistent "vital effect" offset of $0.64 \%$ (Shackleton \& Opdyke, 1973) or $0.83 \%$ (Shackleton, 1974; Herguera et al., 1992) from the calculated $\delta^{18} \mathrm{O}_{\text {eq }}$ using equations such as $\mathrm{O}^{\prime} \mathrm{Neil}$ et al's (1969). Similarly, for many years the benthic foraminifera genus Uvigerina was widely believed to precipitate its shell in oxygen isotopic equilibrium with ambient seawater (Shackleton, 1974). However, core-top Uvigerina from the NW-Pacific are more depleted in ${ }^{18} \mathrm{O}$ than may be predicted from Shackleton's equation, and recent evaluation of the problem indicates that Uvigerina is not in equilibrium (Keigwin, 1998).

Bemis et al. (1998) reevaluated $\delta^{18} \mathrm{O}$ data for planktonic foraminifera from core tops in the North
Atlantic, Pacific and Indian Oceans and in the Arabian Sea and Gulf of Mexico and revised the available paleotemperature equations. The authors proposed a more accurate paleotemperature equation and showed that the Cibicidoides data are in excellent agreement with it and with the equation of Kim \& O'Neil (1997). This agreement suggests that Cibicidoides precipitates its shell near $\delta^{18} \mathrm{O}$ equilibrium with ambient seawater. Conversely, the Uvigerina are relatively rich in ${ }^{18} \mathrm{O}$ and fall primarily into or between the equations of Shackleton (1974) and Erez \& Luz (1983).

Although the two equations tested here yield conflicting results, we believe that as long as we are interested in evaluating relative temperature changes, both equations are useful. However, in order to calculate absolute calcification temperatures it is necessary to know which is the most accurate paleotemperature equation and which genus (if any) precipitates in equilibrium or precipitates with a predictable offset from equilibrium. Among the available equations, that of Kim \& O'Neil (1997) seems to be the most reliable mainly because of the large number of experiments performed with it, the large temperature range and the consistency of the data. According to this equation, Cibicidoides precipitates its shell in oxygen isotopic equilibrium with ambient seawater.

Considering that the oxygen and carbon isotopic analyses are performed on the same foraminifera shells, it is necessary to take into account whether the analyzed benthic foraminifera also precipitates its shell in carbon isotopic equilibrium. It is generally accepted that Cibicidoides is the best recorder of bottom water dissolved inorganic carbon (Belanger et al., 1981; Graham et al., 1981; Duplessy et al., 1984), allowing for reconstructions of past deepocean circulation changes, biological production and nutrient cycling (Broecker \& Peng, 1982; Curry et al., 1988; Oppo et al., 1990). Being epibenthic, Cibicidoides is not affected by pore-water chemistry. Therefore, in paleoceanographic studies the use of Cibicidoides is preferable to the use of Uvigerina.

\section{Conclusions}

The new relationship between $\delta^{18} \mathrm{O}_{\mathrm{w}}$ and salinity developed in this study is particularly important for the estimation of $\delta^{18} \mathrm{O}_{\mathrm{w}}$ based on salinity data in the mid-latitude western South Atlantic. Using the $\delta^{18} \mathrm{O}_{\mathrm{w}}$ values calculated from the new equation and temperature data from GEOSECS stations, predicted isotopic values for calcite precipitated in equilibrium with modern bottom water chemistry were calculated applying the equations of O'Neil et al. (1969) as modified by McCorkle et al. (1997) and Kim \& O'Neil (1997). 
For down-core paleotemperature investigations we suggest applying the latter equation and using the benthic foraminifera Cibicidoides. Our conclusion is supported by several evidences. First of all, Kim \& O'Neil's (1997) equation is considered to be more accurate. According to this equation, Cibicidoides precipitates its shell closer to predicted oxygen isotope equilibrium values (no vital effect). In addition, being epibenthic, Cibicidoides is free from the influence of pore water chemistry. This genus is also considered to precipitate in carbon isotopic equilibrium with ambient seawater. In the absence of sufficient Cibicidoides specimens for oxygen isotopic analyses, ${ }^{18} \mathrm{O}$ Uvigerina may be used data after applying a correction factor of $\quad-0.69 \%$ to account for vital effects.

The results presented here are substantially in agreement with those of other studies of oxygen isotopic variations of benthic foraminifera for the various oceans (McCorkle et al., 1990; Keigwin, 1998; Lynch-Stieglitz et al., 1999) and may potentially improve paleoceanographic interpretations from foraminiferal $\delta^{18} \mathrm{O}$ values in the western South Atlantic.

\section{ACKNOWLEDGEMENTS}

This work was supported financially by the Brazilian National Council for Research and Scientific Development (CNPq). We thank Petrobras for providing the samples. The study benefited greatly from the comments of the two anonymous reviewers. This is the Laboratório de Paleoceanografia do Atlântico Sul (LaPAS), IO-USP's contribution 06.

\section{REFERENCES}

Bainbridge, A. E. 1981. GEOSECS Atlantic Expedition. In Bainbridge, A. E. ed. GEOSECS, Hydrographic Data (1972-1973), 1. Washington, D.C., U.S. Government Printing Office. p. 121

Belanger, P. E.; Curry, W. B. \& Matthews, R. K. 1981. Coretop evaluation of benthic foraminiferal isotopic ratios for paleo-oceanographic interpretations. Palaeogeogr. Palaeoclimatol. Palaeoecol., 33:205-220.

Bemis, B. E.; Spero, H. J.; Bijma, J. \& Lea, D. W. 1998 Reevaluation of the oxygen isotopic composition of planktonic foraminifera: experimental results and revised paleotemperature equations. Paleoceanography, 13(2):150-160.

Berger, W. \& Wefer, G. 1996. Central themes of South Atlantic Circulation. In: Wefer, G.; Berger, W.; Siedler, G. \& Webb, D. eds. The South Atlantic: Present and Past Circulation. Berlin, Springer. p. 1-11.

Bijma, J.; Spero, H. J. \& Lea, D. W. 1999. Reassessing Foraminiferal Stable Isotope Geochemistry: Impact of the Carbonate System (Experimental Results). In: Fisher, G. \& Wefer, G. eds. Use of proxies in paleoceanography: examples from the South Atlantic. Berlin, SpringerVerlag. p. 489-512.

Broecker, W. S. \& Peng, T.-H. 1982. Ice sheets and glacial phosphate - glacial to interglacial changes in ocean chemistry. In: Broecker, W.S .\& Peng, T.-H. eds. Tracers in the sea, Chapter 9. Palisades, New York, LamontDoherty Geological Observatory, Columbia University. p. 334-369.

Craig, H. \& Gordon, L. I. 1965. Isotopic oceanography: Deuterium and Oxygen 18 Variations in the Ocean and the Marine Atmosphere. In: Schink, D. R. \& Corless, J. T. eds. Symposium on Marine Geochemistry, 3. Narragansett, University of Rhode Island. p. 277-374.

Curry, W. B. \& Lohmann, G. P. 1982. Carbon isotopic changes in the benthic foraminifera from the Western South Atlantic: Reconstruction of glacial abyssal circulation patterns. Quat. Res., 18:218-235.

Curry, W. B.; Duplessy, J. C.; Labeyrie, L. D. \& Shackleton, N. J. 1988. Changes in the distribution of $\delta^{13} \mathrm{C}$ of deep water $\Sigma \mathrm{CO}_{2}$ between the last glaciation and the Holocene. Paleoceanography, 3(3):317-341.

Dunbar, R. B. \& Wefer, G. 1984. Stable isotope fractionation in benthic foraminifera from the Peruvian continental margin. Mar. Geol., 59:215-225.

Duplessy, J. C.; Moyes, J. \& Pujol, C. 1980. Deep water formation in the North Atlantic Ocean during the last ice age. Nature, 286 (5772):479-482.

Duplessy, J. C.; Shackleton, N. J.; Matthews, R. K.; Prell, W.; Ruddiman, W. F.; Caralp, M. \& Hendy, C. H. 1984. $\delta^{13} \mathrm{C}$ Record of benthic foraminifera in the last interglacial ocean: implications for the carbon cycle and the global deep water circulation. Quat. Res., 21:225243.

Emiliani, C. 1955. Pleistocene temperatures. J. Geol., 63:538578.

Epstein, S. R.; Buchsbaum, R.; Lowenstam, H. A. \& Urey, H. C. 1953. Revised carbonate-water isotopic temperature scale. Geol. Soc. Am. Bull., 64:1315-1325.

Erez, J. \& Luz, B. 1983. Experimental paleotemperature equation for planktonic foraminifera. Geochim. cosmochim. Acta, 47:1025-1031.

Friedman, I. \& O'Neil, J. R. 1977. Compilation of stable isotope fractionation factors of geochemical interest (Geological Survey Professional Paper 440-KK), In: Fleischer, M. ed. Data of Geochemistry $6^{\text {th }}$ ed. Washington, D.C., U.S. Gov. Print. Off. p. 1-12.

Graham, D.W.; Corliss, B. H.; Bender, M. L. \& Keigwin, L. D. 1981. Carbon and oxygen isotopic disequilibria of Recent deep-sea benthic foraminifera. Mar. Micropaleontol., 6:483-497.

Herguera, J. C.; Jansen, E. \& Berger, W. H. 1992. Evidence for a Bathyal front at 2000-m depth in the glacial Pacific, based on a depth transect on Ontong Java Plateau. Paleoceanography, 7(3):273-288.

Keigwin, L. D. 1998. Glacial-age hydrography of the northwest Pacific Ocean. Paleoceanography, 13(4):323339.

Kim, S.-T. \& O'Neil, J. R. 1997. Equilibrium and nonequilibrium oxygen isotope effects in synthetic carbonates. Geochim. cosmochim. Acta, 61:3461-3475.

Lynch-Stieglitz, J. C.; Curry, W. B. \& Slowey, N. C. 1999. A geostrophic transport estimate for the Florida Current from the oxygen isotopic composition of benthic foraminifera. Paleoceanography, 14(3):360-373. 
McCorkle, D. C.; Keigwin, L. D.; Corliss, B. H. \& Emerson, S. R. 1990. The influence of microhabitats on the carbon isotopic composition of deep-sea benthic foraminifera. Paleoceanography, 5:161-185.

McCorkle, D. C.; Corliss, B. H. \& Farnham, C. A. 1997. Vertical distributions and isotopic composition of live (stained) benthic foraminifera from the North Carolina and Carolina continental margins. Deep Sea Res I, 44(6):983-1024.

McCorkle, D. C.; Heggie, D. T. \& Veeh, H. H. 1998. Glacial and Holocene stable isotope distributions in the southeastern Indian Ocean. Paleoceanography, 13(1):2034.

McCrea, J. M. 1950. On the isotope chemistry of carbonates and a paleotemperature scale. J. Chem. Phys., 18:849857.

Mulitza, S.; Boltovskoy, D.; Donner, B.; Meggers, H.; Paul, A. \& Wefer, G. 2003. Temperature: $\delta^{18} \mathrm{O}$ relationships of planktonic foraminifera collected from surface waters. Palaeogeogr. Palaeoclimatol. Palaeoecol., 202:143-152.

O'Neil, J. R.; Clayton, R. N. \& Mayeda, T. K. 1969. Oxygen isotope fractionation in divalent metal carbonates. J. Chem. Phys., 51:5547-5558.

Oppo, D. W. \& Horowitz, M. 2000. Glacial deep water geometry: South Atlantic benthic foraminiferal $\mathrm{Cd} / \mathrm{Ca}$ and d13C evidence. Paleoceanography, 15:147-160.

Oppo, D. W.; Fairbanks, R. G. \& Gordon, A. L. 1990. Late Pleistocene Southern Ocean $\delta^{13} \mathrm{C}$ variability. Paleoceanography, 5:43-54.

Paul, A.; Mulitza, S.; Pätzold, J. \& Wolff, T. 1999. Simulation of oxygen isotopes in global ocean model. In: Fisher, G. \& Wefer, G. eds. Use of proxies in paleoceanography: examples from the South Atlantic. Berlin, Springer-Verlag. p. 655-686.
Schmiedl, G.; Pfeilsticker, M.; Hemleben, C. \& Mackensen, A. 2004. Environmental and biological effects on the stable composition of recent deep-sea benthic foraminifera from the western Mediterranean Sea. Mar. Micropaleontol., 51:129-152.

Shackleton, N. J. 1967. Oxygen isotope analyses and Pleistocene temperature reassessed. Nature, 215:15-17.

Shackleton, N. J. 1974. Attainment of isotopic equilibrium between ocean water and benthonic foraminifera genus Uvigerina: Isotopic changes in the ocean during the last glacial. Colloq. Int. C.N.R.S., (219):203-209.

Shackleton, N. J. \& Opdyke, N. D. 1973. Oxygen Isotope and Palaeomagnetic Stratigraphy of Equatorial Pacific Core V28-238: Oxygen Isotope Temperatures and Ice Volumes on a $10^{5}$ Year and $10^{6}$ Year Scale. Quat. Res., 3:39-55.

Spero, H. J. 1992. Do planktic foraminifera accurately record shifts in the carbon isotopic composition of sea water $\Sigma \mathrm{CO}_{2}$ ? Mar. Micropaleontol., 19:275-285.

Spero, H. J.; Bijma, J.; Lea, D. W. \& Bemis, B. E. 1997. Effects of seawater carbonate concentration on foraminiferal carbon and oxygen isotopes. Nature, 390:487-500.

Zahn, R. \& Mix, A. C. 1991. Benthic Foraminiferal $\delta^{18}$ O in the Ocean's Temperature-salinity-density Field: Constraints on Ice Age Thermohaline Circulation. Paleoceanography, 6 (1):1-20.

(Manuscript received 23 August 2005; revised 03 February 2006; accepted 24 February 2006) 